\title{
Universitas
}

Review of

\section{COMPANY SIZE, MANAGERIAL, INTITUTIONAL OWNERSHIP AND ENVIRONMENTAL PERFORMANCE ON CORPORATE SOCIAL RESPONSIBILITY DISCLOSURES}

\author{
Liana Mariam Ulfa, Siti Nur Azizah*, Ira Hapsari
}

\begin{abstract}
The purpose of this study is to empirically prove the effect of firm size, board size, institutional ownership, and managerial ownership on CSR disclosure. The sample in this study were mining companies listed on the Indonesia Stock Exchange in 2015-2019 using the purposive sampling method. Based on the criteria, there were 67 samples of research data. The data analysis technique used in this research is descriptive statistical analysis, classical assumption test, multiple linear regression analysis, and hypothesis testing. This study shows that, partially, company size, institutional ownership, and managerial ownership do not affect CSR disclosure. Meanwhile, the environmental performance has a positive effect on CSR disclosure
\end{abstract}

Keywords: Company size, managerial ownership, institutional ownership, environmental performance, and CSR disclosure.

Revised:

October 1, 2021

Accepted:

October 9, 2021

Published:

October 10, 2021

\section{Citation:}

Ulfa. L.M., Azizah. S.N., Santoso. S.B., Hapsari. I. (2021). Company Size, Managerial, Intitutional Ownership And

Environmental Performance On Corporate Social Responsibility Disclosures. RAAR: Review of Applied Accounting Research, 1(2), 75-83.

Office Address:

Jl. K.H. Ahmad

Dahlan, Dukuhwaluh,

Kec. Kembaran, Kab.

Banyumas, Jawa

Tengah 53182

e-ISSN : 2807-8969

\section{ABSTRAK}

Tujuan dari penelitian ini adalah untuk membuktikan secara empiris pengaruh ukuran perusahaan, ukuran dewan, kepemilikan institusional, dan kepemilikan manajerial terhadap pengungkapan CSR. Sampel dalam penelitian ini adalah perusahaan pertambangan yang terdaftar di Bursa Efek Indonesia tahun 2015-2019 dengan menggunakan metode purposive sampling. Berdasarkan kriteria diperoleh 67 sampel data penelitian. Teknik analisis data yang digunakan dalam penelitian ini adalah analisis statistik deskriptif, uji asumsi klasik, analisis regresi linier berganda, dan pengujian hipotesis. Penelitian ini menunjukkan bahwa secara parsial ukuran perusahaan, kepemilikan institusional, dan kepemilikan manajerial tidak berpengaruh terhadap pengungkapan CSR. Sedangkan kinerja lingkungan berpengaruh positif terhadap pengungkapan CSR

Kata kunci: Ukuran perusahaan, kepemilikan manajerial, kepemilikan institusional, kinerja lingkungan, dan pengungkapan CSR. 


\section{INTRODUCTION}

Economic growth in a company can lead to tight business competition between companies (Anindityo and Ardiyanto, 2013). Business competition between companies can occur with company activities. The activities of a company have several impacts, including positive ones. The positive impact that occurs due to the activities of a company is the occurrence of jobs, development and processing of natural resources (SDA) and human resources (SDM) as well as increasing economic growth (Putri et al. 2013).

Increasing the company's economy in building a good name is one way to achieve profit, in other words the company shows its social responsibility in the community (Darma, et al. 2019). Corporate Social Responsibility is an action to carry out obligations towards all company interests based on decisions in making policies and actions towards stakeholders and the environment around the company in accordance with the provisions of the existing laws. No 40/2007 article 74 paragraph (1) on limited liability companies. Social and environmental responsibility obligations carried out by a business sector or company (Fauziah and Asyik, 2019).

\section{LITERATURE REVIEW}

\section{Legitimacy Theory}

Legitimacy is defined as a social contral operating between the company and the community (Pramesti and Idayanti, 2019). Legitimacy theory is a theory in which the organization's operational activities in the external environment can change continuously and companies pay attention to social norms that exist in the community where the company is part of the social environment (Kusumawati, R. R. 2018).

Companies that are considered important for legitimacy theory are due to the existence of one of the factors that will become the company's strategy in the future. This organizational strategy can be seen from the community providing social norms to the company, then the company needs good supervision of management performance as well as disclosing information in order to maintain public trust in the company (Nuraini, 2018).

Thus, CSR disclosure related to the legitimacy theory of the company can make a positive contribution to society by making the community welfare so that it can create a good environment and the company maximizes the company's activities so that it can be accepted by the community because CSR disclosure will show the level of compliance in a company ( Fitriyah, et al 2018).

\section{Agency Theory}

According to Jensen and Meckling (1976) agency theory is a theory that reveals the contractual relationship between the principal or company owner and the agent or company manager. The contractual relationship is a contract that will cause agency problems, namely due to a conflict of interest differences between the company owner and the company manager. Meanwhile, the principal or company owner is the party who delegates decision-making authority to the agent (Fitriyah, et al. 2018).

Agency theory also explains the issue of information asymmetry. Information asymmetry is a situation that is not balanced with the acquisition of information between management and shareholders (Prasetio and Suryono, 2016). This asymmetry occurs because there is a 
principal because the principal has less information than the agent. Meanwhile, agents as managers know more about extensive information about the company (Yamaditya and Raharja, 2014).

Agency theory can affect the disclosure of social responsibility (CSR), namely the cost of supervision and the cost of corporate social contracts (Amilia, D. S. 2019). Firms that experience low supervisory and social contral costs tend to report lower returns and the manager as agent can fulfill the wishes of the principal.

\section{METHOD}

The population in this study were all mining companies listed on the Indonesia Stock Exchange 2015-2019. The techniques in this study used purposive sampling. Purposive sampling determines certain criteria.

Determination of the sample with the following criteria:

1. Mining companies listed on the Indonesia Stock Exchange in 2015-2019.

2. Mining companies that fully disclose and present the data needed in this study, namely company size, managerial ownership, institutional ownership, environmental performance and CSR disclosure during the 2015-2019 period.

\section{RESULT}

\begin{tabular}{|c|c|c|c|c|}
\hline & Standardized Residual & Expla & ation & \\
\hline $\mathrm{N}$ & 67 & & & \\
\hline Kolmogorov-Smirnov Z & $\mathbf{0 , 5 3 9}$ & & & \\
\hline Asymp. Sig. (2-tailed) & 0,933 & Pass & the & Normality \\
\hline
\end{tabular}

The results of the normality test on 67 samples show that the normality assumption in the regression model is fulfilled. This is indicated by a significance value greater than 0,05 or a significance value of $0,933>0,05$. This shows that the data has a normal distribution.

\begin{tabular}{llll}
\hline Variable & Tolerance & VIF & Explanation \\
\hline Company Size & 0,801 & 1,248 & Multicollinearity Free \\
Managerial Ownership & 0,687 & 1,456 & Multicollinearity Free \\
Institutional Ownership & 0,588 & 1,699 & Multicollinearity Free \\
Environmental Performance & 0,945 & 1,058 & Multicollinearity Free \\
\hline
\end{tabular}

The multicollinearity test results show that the tolerance value for all independent variables if the tolerance value is $>0,10$ and VIF $<0,10$. So it can be concluded that the data does not experience multicollinearity problems.

\begin{tabular}{lll}
\hline Variable & Sig. & Explanation \\
\hline Company Size & 0,222 & Heteroscedasticity Free \\
Managerial Ownership & 0,349 & Heteroscedasticity Free \\
Institutional Ownership & 0,117 & Heteroscedasticity Free \\
\hline
\end{tabular}




\begin{tabular}{lll}
\hline Environmental Performance & 0,621 & Heteroscedasticity Free \\
\hline
\end{tabular}

Based on the heteroscedasticity test using the Glejser method, it shows that the independent variables above have a significant value above 0.05 , which indicates that the table does not have any symptoms of heteroscesdasticity.

\begin{tabular}{lllllll}
\hline & & \multicolumn{5}{c}{ Model Summary $^{\mathbf{b}}$} \\
\hline $\begin{array}{l}\text { Mode } \\
\mathbf{l}\end{array}$ & $\mathbf{R}$ & R Square & $\begin{array}{l}\text { Adjusted } \\
\text { Square }\end{array}$ & $\begin{array}{l}\text { Std. Error of } \\
\text { the Estimate }\end{array}$ & $\begin{array}{l}\text { Durbin- } \\
\text { Watson }\end{array}$ \\
\hline 1 & $0,461^{\mathrm{a}}$ & 0,213 & 0,162 & 63,79573 & 1,215 \\
\hline
\end{tabular}

Based on the results above, it can be seen that the DW value generated from the regression model is 1,215 . This means that the value of DW $(1,215)$ lies between -2 and $+2(-2<\mathrm{DW}<+2)$, so it can be concluded that there is no autocorrelation problem.

\begin{tabular}{llllll}
\hline Variable & \multicolumn{2}{l}{$\begin{array}{l}\text { Unstandardized } \\
\text { Coefficients }\end{array}$} & \multicolumn{2}{l}{$\begin{array}{l}\text { Standardized } \\
\text { Coefficients }\end{array}$} & \\
& B & Std.Error & Beta & T & Sig. \\
\hline Constanta & $-257,903$ & 177,587 & & $-1,452$ & 0,152 \\
Company Size & 0,007 & 0,006 & 0,134 & 1,063 & 0,292 \\
Managerial Ownership & $-0,030$ & 0,044 & $-0,091$ & $-0,672$ & 0,504 \\
Institutional Ownership & 0,031 & 0,041 & 0,110 & 0,746 & 0,458 \\
Environmental & 42,982 & 15,205 & $-0,328$ & 2,827 & 0,006 \\
Performance & & & & & \\
\hline
\end{tabular}

Model Summary

\begin{tabular}{llllll}
$\begin{array}{l}\text { Mode } \\
\mathbf{l}\end{array}$ & $\mathbf{R}$ & R Square & $\begin{array}{l}\text { Adjusted } \\
\text { Square }\end{array}$ & $\mathbf{R}$ & $\begin{array}{l}\text { Std. Error of the } \\
\text { Estimate }\end{array}$ \\
\hline 1 & $0,461^{\mathrm{a}}$ & 0,213 & 0,162 & 63,79573 \\
\hline
\end{tabular}

Based on the research table, the Adjusted Square value is 0,162 , this value indicates that the independent variables, namely company size, managerial ownership, institutional ownership, and environmental performance can explain the variation in the dependent variable, namely CSR disclosure of $16,2 \%$. While the remaining $83,8 \%$ is explained by other variables such as the size of the board of commissioners, the type of industry and others that are not included in this study. 
ANOVA $^{\mathrm{a}}$

79

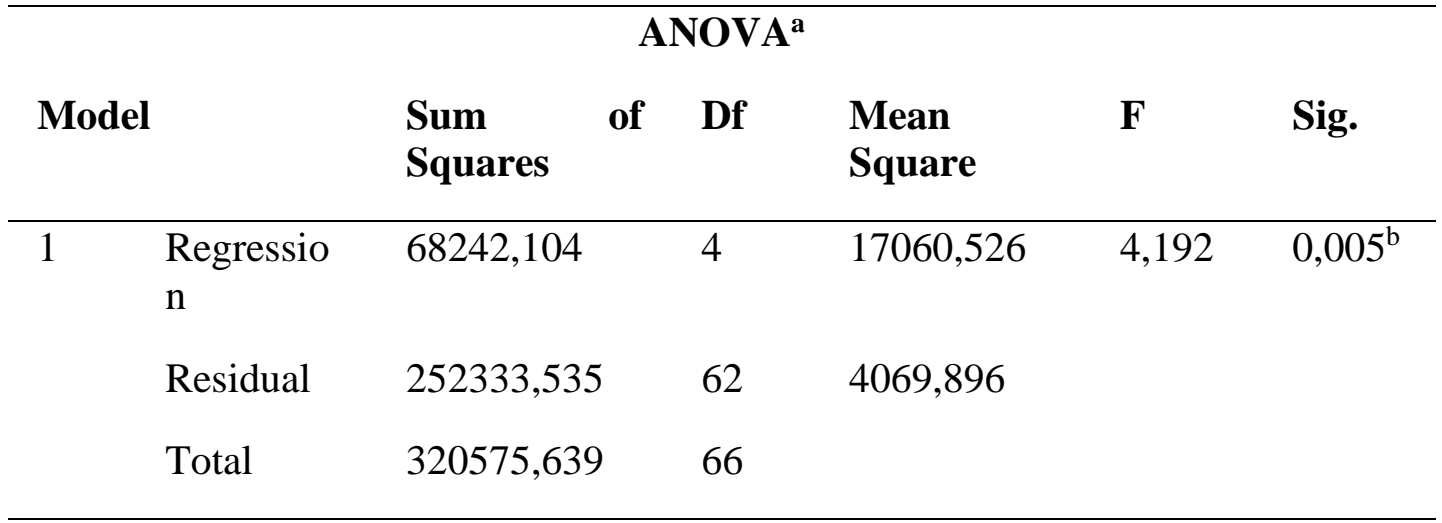

Based on the research results, the $\mathrm{F}$ statistical test results have a significance value of 0.005 , which means $0,005<0,05$. So it can be concluded that all independent variables simultaneously affect the dependent variable, namely CSR disclosure, so this research model is accepted.

\section{Statistical Test Result}

\begin{tabular}{|c|c|c|c|c|c|}
\hline \multirow[t]{2}{*}{ Variable } & \multicolumn{2}{|c|}{$\begin{array}{l}\text { Unstandardized } \\
\text { Coefficients }\end{array}$} & \multicolumn{3}{|c|}{$\begin{array}{l}\text { Standardized } \\
\text { Coefficients }\end{array}$} \\
\hline & B & Std. Error & Beta & $\mathrm{T}$ & Sig. \\
\hline Constanta & $-257,903$ & 177,587 & & $-1,452$ & 0,152 \\
\hline Company Size & 0,007 & 0,006 & 0,134 & 1,063 & 0,292 \\
\hline Managerial & $-0,030$ & 0,044 & $-0,091$ & $-0,672$ & 0,504 \\
\hline Institutional & 0,031 & 0,041 & 0,110 & 0,746 & 0,458 \\
\hline $\begin{array}{l}\text { Environmental } \\
\text { Performance }\end{array}$ & 42,982 & 15,205 & $-0,328$ & 2,827 & 0,006 \\
\hline
\end{tabular}

\section{Discussion}

\section{a. First Hypothesis testing Result}

The results of the partial test of the effect of company size on CSR disclosure obtained a tcount of 1,603 with a significant value of 0,292 and a table of 1,66980 and a regression coefficient of 0,007 . Because the t-count value is smaller than t-table and the significance value is $>0,05$, it can be concluded that the firm size variable has no effect on CSR disclosure. So it can be said that the first hypothesis states that company size has no effect on CSR disclosure.

According to agency theory, it is explained that a company that has high agency costs will disclose information related to broad CSR disclosure to reduce agency costs (Pramesti and Idayanti, 2019). However, in the results of this study, company size has no effect on CSR disclosure because the size of the company does not affect changes in CSR disclosure. This means that when the company size has increased or decreased, it will not affect CSR disclosure. The results of this study support research conducted by Pradana and Suzan (2016), Khairunnisa (2019), Pratiwi (2020) and Shafira et al (2021) which state that company size has no effect on CSR disclosure. 


\section{b. Second Hypothesis Testing Results}

Based on the table above, the partial test results of the effect of managerial ownership on CSR disclosure obtained a t-count value of $-0,672$ with a significant value of 0,504 and a t-table of 1,66980 and a regression coefficient of $-0,030$. Because the t-value is smaller than t-table and the significance value is $>0,05$, it can be concluded that the managerial ownership variable has no effect on CSR disclosure. So it can be said that the second hypothesis states that managerial ownership has no effect on CSR disclosure.

Based on agency theory, companies have problems that arise between shareholders and managers due to the small value of their share ownership by agents in a company (Sukasih and Sugiyanto, 2017). The absence of influence between managerial ownership and CSR disclosure means that changes in the value of managerial ownership will not have an effect on CSR disclosure, because management is more focused on increasing corporate profits which will benefit them and the company owner than on CSR disclosure. The results of this study support with research conducted by Trisnawati (2014), Sari and Rani (2015) and Elvina, et al (2016) which state that managerial ownership has no effect on CSR disclosure.

\section{c. Third Hypothesis Testing Results}

Based on the table above, the partial test results of the effect of institutional ownership on CSR disclosure obtained a t-count value of 0,746 with a significant value of 0,458 and a t-table of 1,66980 and a regression coefficient of 0,031 . Because the t-count is smaller than t-table and the significance value is $>0,05$, it can be concluded that institutional ownership has no effect on CSR disclosure. So it can be said that the third hypothesis states that institutional ownership has no effect on CSR disclosure.

Based on the legitimacy theory which explains that the large value of institutional ownership, the company will tend to disclose wider CSR. This is because institutional share ownership has not considered social responsibility as one of the criteria for investing, so that investors do not emphasize companies to disclose CSR components in detail and do not make disclosure an obligation in a company. Therefore, there is no demand for companies to disclose information related to CSR disclosure in the company's financial statements (Putri and Gunawan, 2019). The results of this study support the research conducted by Hany and Nurfrianto (2016), Andarsari (2019) and Rahmasari (2020) which state that institutional ownership has no effect on CSR disclosure.

\section{d. Fourth Hypothesis Testing Results}

Based on the table above, the partial test results of the effect of environmental performance on CSR disclosure obtained a t-count value of 2,827 with a significant value of 0,006 and a t-table of 1,66980 and a regression coefficient with a positive direction of 42,982. Because the t-count value is greater than t-table and the significance value is $<0,05$, it can be concluded that environmental performance variables have a positive effect on CSR disclosure. So it can be said that the fourth hypothesis states that environmental performance has a positive effect on CSR disclosure.

RAAR Vol.1 No.2 
Based on the theory of legitimacy, it explains that in a company that has good environmental performance, the company will pay attention to the environment and can realize corporate social responsibility to society. This is because companies have social contracts related to the environment and social responsibility to society (Darma, et al. 2019). The results of this study support the research conducted by Kusuma, et al. (2014), Tandirerung (2019) and Kustina (2020) which state that environmental performance has a positive effect on CSR disclosure.

\section{CONCLUSIONS AND SUGGESTIONS}

Based on the results of tests that have been carried out on mining companies listed on the IDX in 2015-2019, the following conclusions can be drawn:

1. Company size has no effect on CSR disclosure.

2. Managerial ownership has no effect on CSR disclosure.

3. Institutional ownership has no effect on CSR disclosure.

4. Environmental performance has a positive effect on CSR disclosure.

\section{REFERENCES}

Alwi, H. (2019). Pengaruh Karakteristik Perusahaan dan Good Corporate Governance Terhadap Pengungkapan Corporate Social Responsibility. Akuntansi dewantara, 3(2), 119-128.

Amilia, S. D. (2019). Pengaruh Profitabilitas, Leverage, dan Ukuran Perusahaan Terhadap Pengungkapan Corporate Social Responsibility. Jurnal Ilmu dan Riset Akuntansi (JIRA), 8(11).4-5

Andarsari, P. R. (2019). The Effect of Firm Size, Gross Profit Margin and Institutional Ownership on Disclosure of Corporate Social Responsibility (CSR). E-Jurnal Apresiasi Ekonomi, 7(3)

Anindito, T., \& Ardiyanto, M. D. (2013). Pengaruh Kinerja Lingkungan Terhadap Corporate Social Responsibility (CSR) Disclosure dan Kinerja Finansial Perusahaan Kimia dan Pertambangan Yang Terdaftar Di Bursa Efek Indonesia. Studi Empiris Pada Perusahaan Pertambangan Yang Terdaftar dalam BEI tahun. Diponegoro Journal of Accounting, 2(1). 329-340.

Darma, B. D., Arza, F. I., \& Halmawati, H. (2019). Pengaruh Pengungkapan Media, Kinerja Lingkungan Dan Kepemilikan Asing Terhadap Pengungkapan Corporate Social Responsbility. Jurnal eksplorasi akuntansi, 1(1), 78-89.

Fauziah, I., \& Asyik, N. F. (2019). Pengaruh Profitabilitas, Likuiditas, Leverage, Ukuran Perusahaan dan Ukuran Dewan Komisaris Terhadap Pengungkapan Corporate Social Responsibility. Jurnal Ilmu dan Riset Akuntansi (JIRA), 8(3), 1-17.

RAAR Fitriyah, A., Malia, E., \& Faisol, I. A. (2018). Pengaruh Profitabilitas Size Perusahaan, Vol.1 No.2

Leverage, Likuiditas, Tipe Industri dan Kepemilikan Publik Terhadap Pengungkapan Corporate Social Responsibility pada Perusahaan Telekomunikasi yang terdaftar di Bursa Efek Indonesia. In Prosiding Seminar Nasional Ekonomi, Manajemen, dan Akuntansi (SINEMA).1(1). 1-12. 
Hamzah, A. (2019). Pengaruh Kinerja Lingkungan, Profitabilitas, Likuiditas dan Kepemilikian Institusional Terhadap Pengungkapan Tanggung Jawab Sosial Perusahaan (Studi Empiris pada Perusahaan Sub Sektor Pertambangan Batubara yang Terdaftar di Bursa Efek Indonesia Periode 20. JIFA (Journal of Islamic Finance and Accounting), 2(2). 100-117

Hanny, R., \& Nurfrianto, A. F. (2016). Pengaruh karakteristik perusahaan terhadap pengungkapan corporate social responsiblity. Jurnal Ilmu Administrasi: Media Pengembangan Ilmu dan Praktek Administrasi, 13(3), 547-560

Jensen, M.C., dan Meckling, W.H. (1976). Theory of the Firm: Managerial Behavior, Agency Costs and Ownership Structure, 3, 305-360.

Kurnianingsih, H. T. (2014). Pengaruh Profitabilitas Dan Size Perusahaan Terhadap Corporate Social Responsibility. JRAB: Jurnal Riset Akuntansi \& Bisnis, 13(1). 93-111.

Kustina, T. (2020). Pengaruh Kinerja Lingkungan, Sensitivitas Industri, dan Ukuran Perusahaan, Terhadap Pengungkapan Corporate Social Responsibility di Perusahaan Manufaktur Yang Terdaftar di Bursa Efek Indonesia. Krisna: kumpulan riset akuntansi, 12(1), 113-125.

Kusumawati, R. R. (2018). Pengaruh Kepemilikan Institusional Dan Kepemilikan Asing Terhadap Pengungkapan Corporate Social Responsibility Pada Perusahaan Lq-45 Yang Terdaftar Di Bursa Efek Indonesia. Publik, 14(1), 63-74.

Nurrahman, A., \& Sudarno, S. (2013). Pengaruh Kepemilikan Manajerial, Kepemilikan Institusional, dan Kepemilikan Asing Terhadap Praktik Pengungkapan Sustainability Report. Diponegoro Journal of Accounting, 2(1). 273-285.

Nuraini, Nani. Effendi, Bahtiar \& Setiadi, Iwan. (2018). Corporate Governance dan Environmental Disclosure. Jurnal Ilmiah Akuntansi dan Pariwisata, 1(2), 19-30.

Patmawati, S. (2020). Pengaruh Kepemilikan Institusional, Profitabilitas Dan Ukuran Perusahaan Terhadap Corporate Social Responsibility pada perusahaan Investasi Yang Terdaftar Di Bursa Efek Indonesia Periode 2016-2018. Jurnal Cano Ekonomos, 8(2), 18-24.

Pradana dan Zusan (2016). Pengaruh Struktur Kepemilikan, Ukuran Perusahaan, dan Umur Perusahaan Terhadap Pengungkapan Corporate Social Responsibility. Jurnal. Fakultas Ekonomi dan Bisnis Universitas Telkom, 3.(1), 339.

Putri, T. R., Sari, R. N., \& Sari, R. N. (2013). Pengaruh Kepemilikan Asing, Kinerja Lingkungan Dan Pengaruh Politik Terhadap Luas Pengungkapan Corporate Social Responsibility Pada Perusahaan Pertambangan Yang Terdaftar Di Bursa Efek Indonesia. Jurnal Sosial Ekonomi Pembangunan, 3(9), 268-285.

Putri, E. I., \& Gunawan, B. (2019). Analisis Pengaruh Karakteristik Perusahaan, Ukuran Dewan Komisaris, dan Struktur Kepemilikan terhadap Pengungkapan Corporate Social Responsibility di Perusahaan Property dan Real Estate. Seminar Nasional dan The 6th Call for Syariah Paper (SANCALL) 2019. 2(1) 388-406.

\section{RAAR}

Vol.1 No.2 
Rofiqkoh, E., \& Priyadi, M. P. (2016). Pengaruh Profitabilitas, Leverage dan Ukuran Perusahaan T erhadap Pengungkapan Tanggung Jawab Sosial Perusahaan. Jurnal Ilmu Dan Riset Akuntansi (JIRA), 5(10). 1-18.

Sari, W. N., \& Rani, P. (2015). Pengaruh Kepemilikan Institusional, Kepemilikan Manajerial, Return On Assets (ROA) dan Ukuran Perusahaan Terhadap Pengungkapan Corporate Social Responsibility (CSR) Pada Perusahaan Manufaktur Yang Terdaftar Di Bursa Efek Indonesia Periode 2011-2013. Jurnal Akuntansi Dan Keuangan, 4(1). 1-20.

Shafira, R. N., Azizah, S. N., Wahyuni, S., \& Pramono, H. (2021). The Effect of Firm Size and Corporate Governance Structure on Corporate Social Responsibility Disclosures. Muhammadiyah Riau Accounting and Business Journal, 2(2), 163169.

Sukasih, A., \& Sugiyanto, E. (2017). Pengaruh Struktur Good Corporate Governance dan Kinerja Lingkungan Terhadap Pengungkapan Corporate Social Responsibility (Studi pada perusahaan manufaktur di Bursa Efek Indonesia Periode 20112015). Riset Akuntansi dan Keuangan Indonesia, 2(2), 121-131.

Wahas, E. A., \& Hermanto, S. B. (2018). Pengaruh Profitabilitas, Leverage dan Tata Kelola Perusahaan Terhadap Pengungkapan Corporate Social Responsibility. Jurnal Ilmu dan Riset Akuntansi (JIRA), 7(11). 1-24.

Yamaditya, V., dan Raharja. (2014). Pengaruh Asimetri Informasi, Leverage, dan Ukuran Perusahaan Terhadap Praktik Manajemen Laba. Diponegoro Journal of Accounting, 3(4), 1-12. 